DOI: 10.20472/IAC.2018.038.025

\title{
KANIBHATTI NITIROJNTANAD
}

Chulalongkorn University, Thailand

\section{CORPORATE GOVERNANCE SCORE AND EARNINGS QUALITY OF COMPANIES LISTED IN THE STOCK EXCHANGE OF THAILAND}

\begin{abstract}
:
The purpose of this study is to examine the relationship between corporate governance score and earnings quality of companies listed in the Stock Exchange of Thailand. This study used secondary data of companies in the Stock Exchange of Thailand in all industrial groups excluding companies in the market for alternative investment, business financial group, as well as the rehabilitation companies. The sample included companies with corporate governance score which corresponding to "Excellent" and "Very Good" recognition level in the year 2014 and 2015. The data was analyzed using regression analysis.
\end{abstract}

In this study, the earnings quality is measured in terms of discretionary accruals and standard deviation of net income. The results suggested that corporate governance score was negatively related to discretionary accruals indicating positive relationship between corporate governance score and earnings quality. Corporate governance score was also found positively related to cash flows return to total assets. However, corporate governance score was not found to be significantly related to standard deviation of net income.

The results of this study implied that corporate governance scores, based on the recognition level of the National Committee on Corporate Governance, are likely to represent earnings quality of listed companies in the Stock Exchange of Thailand in the context of discretionary accruals and cash flows return to total assets.

\section{Keywords:}

corporate governance, corporate governance score, earnings quality, discretionary accurals, cash flows return to total assets

JEL Classification: M00, G30 